\title{
STX2 wt Allele
}

National Cancer Institute

\section{Source}

National Cancer Institute. STX2 wt Allele. NCI Thesaurus. Code C116089.

Human STX2 wild-type allele is located in the vicinity of 12 q24.33 and is approximately 50 $\mathrm{kb}$ in length. This allele, which encodes syntaxin-2 protein, is involved in both vesicular transport and epithelial morphogenesis. 